\title{
Seasonal performance of aquatic macrophytes in improving physicochemical parameters of swine wastewater
}

\author{
C. D. Pinaffi* (D), A. P. J. Scandelai ${ }^{\text {(D) }}$ and C. H. Santos ${ }^{a}$ \\ aPrograma de Pós-Graduação em Agronomia/Produção Vegetal, Universidade do Oeste Paulista - UNOESTE, Rodovia \\ Raposo Tavares, km 572, Limoeiro, CEP 19067-175, Presidente Prudente, SP, Brasil \\ ${ }^{\text {b} D e p a r t a m e n t o ~ d e ~ E n g e n h a r i a ~ Q u i ́ m i c a, ~ U n i v e r s i d a d e ~ E s t a d u a l ~ d e ~ M a r i n g a ́ ~-~ U E M, ~ A v . ~ C o l o m b o, ~ 5790, ~ C E P ~ 87020-900, ~}$ \\ Jardim Universitário, Maringá, PR, Brasil \\ *e-mail: camila_pinaffi@hotmail.com
}

Received: June 22, 2019 - Accepted: August 1, 2019 - Distributed: November 30, 2020

(With 8 figures)

\begin{abstract}
Swine wastewaters (SW) present organic load and nutrient content, what have caused degradation of water quality in many watercourses. Thus, the aquatic macrophytes represent an alternative for the depollution of these wastewaters, due to the high recovery power. The aim of this study was to evaluate the performance of the Eichhornia crassipes (Mart.) Solms, Pistia stratiotes L. and Salvinia auriculata Aubl. in improving the physicochemical targets of SW, as well as to quantify the total ammoniacal nitrogen $\left(\mathrm{NH}_{4}^{+}\right)$and total phosphorus (total $\left.\mathrm{P}\right)$ in the plant tissue of the macrophytes and the dry matter biomass (DMB) in two seasons of the year (spring and winter). The experiment was designed in a randomized block design, with 4 treatments $(\mathrm{T})$ with 4 replicates: $\mathrm{T} 1=$ Control (without plants); $\mathrm{T} 2=$ E. crassipes $; \mathrm{T} 3=P$. stratiotes $;$ and $\mathrm{T} 4=S$. auriculata , submitted to a $\mathrm{SW}$ diluted in $50 \%$ water. The monitoring is done in tanks during a period of 30 days of each season. Electrical conductivity (EC), dissolved oxygen (DO), turbidity, $\mathrm{NH}_{4}^{+}$and dissolved phosphorus (P) were analyzed in the $\mathrm{SW}$. In the plants, the contents of $\mathrm{NH}_{4}^{+}$, total $\mathrm{P}$ and DMB were determined. It was verified that, in the spring, the plants showed higher production of DMB and a more significant reduction of $\mathrm{EC}, \mathrm{NH}_{4}^{+}$and $\mathrm{P}$, when compared to the plants managed in the $\mathrm{SW}$ in the winter. E. crassipes was more efficient at removing $\mathrm{P}(39 \%)$ and total $\mathrm{NH}_{4}^{+}(80.2 \%)$, and $\mathrm{EC}$ reducing $(92 \%)$ of $\mathrm{SW}$ and DMB production in the spring. The results demonstrated that the $\mathrm{NH}_{4}^{+}$uptake by E. crassipes contributed to a considerable removal of $\mathrm{NH}_{4}^{+}$and $\mathrm{P}$ from SW.
\end{abstract}

Keywords: pollution, physicochemical parameters, Eichhornia crassipes (Mart.) Solms, Pistia stratiotes L., Salvinia auriculata Aubl.

\section{Desempenho sazonal de macrófitas aquáticas na melhoria de parâmetros físico-químicos de efluente de suinocultura}

\section{Resumo}

Os efluentes da suinocultura apresentam elevado teor de carga orgânica e de nutrientes, o que dificulta o seu tratamento. Dessa forma, as macrófitas aquáticas representam uma alternativa para a despoluição desses efluentes, devido ao alto poder de absorção que essas plantas possuem. Neste contexto, o objetivo deste estudo foi avaliar o desempenho das plantas Eichhornia crassipes (Mart.) Solms, Pistia stratiotes L. e Salvinia auriculata Aubl. na melhoria das características físico-químicas de um efluente de suinocultura, bem como quantificar o teor dos elementos nitrogênio amoniacal total $\left(\mathrm{NH}_{4}^{+}\right)$e fósforo total (P total) no tecido vegetal das macrófitas e a biomassa de matéria seca (BMS) produzida em duas estações do ano (primavera e inverno). O experimento compreendeu delineamento em blocos casualizados, com 4 tratamentos $(\mathrm{T})$ com 4 repetições, sendo eles: $\mathrm{T} 1=$ Testemunha (sem plantas); $\mathrm{T} 2=$ E. crassipes; $\mathrm{T} 3=P$. stratiotes; e T4 $=$ S. auriculata, submetidos a efluente de suinocultura diluídos em $50 \%$ de água. O cultivo ocorreu em tanques instalados ao ar livre durante 30 dias de cada estação. Foram analisados, nos efluentes, os parâmetros de condutividade elétrica (CE), oxigênio dissolvido (OD), $\mathrm{pH}$, turbidez, $\mathrm{NH}_{4}{ }^{+}$e fósforo disponível (P). Nas plantas, foram determinados os teores de $\mathrm{NH}_{4}^{+}$, P total e BMS. Foi verificado que, na primavera, as plantas apresentaram maior produção de BMS e redução mais expressiva de $\mathrm{CE}, \mathrm{NH}_{4}^{+} \mathrm{e}$, quando comparadas às plantas manejadas no efluente suíno no inverno. A E. crassipes foi mais eficiente na remoção de $\mathrm{P}(39 \%)$ e $\mathrm{NH}_{4}{ }^{+}$total $(80,2 \%)$, e na redução da $\mathrm{CE}(92 \%)$ do efluente suíno e na produção de biomassa seca, na primavera.

Palavras-chave: poluição, parâmetros físico-químicos, Eichhornia crassipes (Mart.) Solms, Pistia stratiotes L., Salvinia auriculata Aubl. 


\section{Introduction}

Pig farming represents an activity of great importance to economy, since the pork is classified as the most consumed source of animal protein in the world (ABCS, 2016). Nonetheless, pig farming is considered an activity that has environmental impacts, mainly regarding the wastewater generation with high concentration of suspended solids, organic matter, nutrients and pathogens (Rodrigues et al., 2010; Song et al., 2010). In view of these characteristics, it is indispensable to carry out a treatment system with significant improvement in the quality of such wastewater, as well as the possibility of its disposal.

Several systems can be used for treating swine wastewaters, among them, the usage of aquatic macrophytes, which comprise one of the most productive aquatic communities, presenting an important role in the nutrient dynamics. It happens due to the efficiency of these plants in reducing the concentration of organic pollutants through microbiological and biochemical processes, which promote organic matter decomposition, nutrient mineralization and removal of pathogens. Besides, they mediate the physicochemical processes, as filtration, adsorption and sedimentation (Białowiec et al., 2011; Shelef et al., 2013).

There are numerous plant species active and suitable for cultivation in wastewater treatment systems, and those occurring naturally in the region, which also tolerate the anoxic conditions of these systems, are the most wanted (Amorim et al., 2015). The aquatic macrophytes present a relatively fast life cycle and reproduce both sexually and asexually, allowing a greater success in growth and propagation. However, climatic conditions, nutrient concentration, free space between the plants and turbulence and mixing conditions interfere with their growth. Lentic aquatic systems of tropical regions represent ideal conditions for the development of macrophytes throughout the year (Camargo and Esteves, 1995).

In this sense, the present work aims to assess the performance of the plants Eichhornia crassipes, Pistia stratiotes and Salvinia auriculata in the improvement of physicochemical characteristics of swine wastewater (SW), as well as quantifying the content of the elements $\mathrm{NH}_{4}^{+}$and total $\mathrm{P}$ in the plant tissue of the plants and the dry matter biomass (DMB) produced in two seasons of year, considering the changes in the weather conditions of the environment.

\section{Material and Methods}

\subsection{Outline of the experiment}

The treatments were carried out in 16 polyvinyl chloride (PVC) tanks installed outdoors (Campus II of Universidade do Oeste Paulista - UNOESTE, Presidente Prudente, SP, Brazil, $22^{\circ} 07^{\prime} \mathrm{S}$ and $\left.51^{\circ} 09^{\prime} \mathrm{W}\right)$. The tanks had $76.5 \mathrm{~cm}$ in height, $101.5 \mathrm{~cm}$ in top diameter and $73 \mathrm{~cm}$ bottom diameter, making a stored volume of $0.32 \mathrm{~m}^{3}$, in which only $0.25 \mathrm{~m}^{3}$ is used by container. The local climate, according to Köppen, is defined as rainy tropical with dry winter, with average annual temperature of $29.2^{\circ} \mathrm{C}$. The mean annual precipitation is $1254.9 \mathrm{~mm}$, in which July is the dry month, when only $33.8 \mathrm{~mm}$ occur.

The experimental outline used was characterized as randomized blocks design, in split plots containing four treatments with four replicates: $\mathrm{T} 1=\mathrm{Control}(50 \% \mathrm{SW}$ and $50 \%$ water); $\mathrm{T} 2=50 \% \mathrm{SW}$ and $50 \%$ water + E. crassipes; $\mathrm{T} 3=50 \% \mathrm{SW}$ and $50 \%$ water $+P$. stratiotes; $\mathrm{T} 4=50 \%$ $\mathrm{SW}$ and $50 \%$ water $+S$. auriculata. The plots represented the treatments (with and without the presence of aquatic plants) and the subplots, the periods of SW collection for analysis $(0,7,14,21$ and 30 days).

\subsection{Physicochemical analysis of the swine wastewater}

The wastewater used in the study came from the swine activity of the zootechnical center of this university and it was characterized physicochemically, before beginning the treatment with the macrophytes. Afterwards, from the beginning of the experiment, samples of the wastewater were collected weekly $(0,7,14,21$ and 30 days), which were characterized by the analysis of parameters of dissolved oxygen (DO), electrical conductivity (EC), turbidity. The concentration of the total ammoniacal nitrogen $\left(\mathrm{NH}_{4}^{+}\right)$ and dissolved phosphorus $(\mathrm{P})$ were also determined, at the beginning of the experiment and on the 30th day.

The DO and EC readings were carried out by the potentiometric method, using a portable dissolved oxygen meter (Hanna Instruments, model HI 9146) and a digital conductivity meter (Hanna Instruments, model: HI 2300), respectively. The turbidity was performed through the nephelometric method using a microprocessor based turbidity meter (model: Q279P Quimis). The determination of the $\mathrm{NH}_{4}^{+}$content was obtained by the Kjeldahl method, which consists of three steps: acid digestion, distillation in nitrogen distiller (Tecnal, model: TE-0364) and sulfuric acid titration. To quantify the $\mathrm{P}$ available in the wastewater, samples were filtered in slow filter paper and, subsequently, read in spectrophotometer (Lambda XLS +, PerkiElmer), using the UV-Vis spectrophotometer at $420 \mathrm{~nm}$. Both determinations, $\mathrm{NH}_{4}^{+}$and $\mathrm{P}$, were performed according to Malavolta et al. (1997).

\subsection{Chemical analysis of the plant tissue of aquatic macrophytes}

The aquatic macrophytes Eichhornia crassipes (water hyacinth), Pistia stratiotes (water lettuce) and Salvinia auriculata (eared watermoss) were collected in preserved ecosystems, located in the western region of the state of São Paulo, Brazil, and are characterized as young plants, with uniform size, formed root system and aerial part with appearance similar to each other. After the collection, they were placed into boxes containing fresh water, as a way of making their environmental adaptability happen, for a week. Subsequently to this period, the macrophytes water hyacinth, water lettuce and eared watermoss were inserted into their respective treatment systems (T2, T3 and T4, respectively), and their biomass was evenly distributed, in order to cover, approximately, $80 \%$ 
of the surfaces of the tanks, as indicated by Henry-Silva and Camargo (2008). Figure 1 presents the plants at the beginning of the experiment and their development after 30 days staying in the treatment systems.

The plants were collected 30 days after implanting the treatments and were sent to the chemical analysis of the elements $\mathrm{NH}_{4}^{+}$and $\mathrm{P}$ total, according to Malavolta et al. (1997).

\subsection{Characterization of the experimentation periods}

The experimental evaluation occurred in two periods, one characterized by higher temperatures and higher rainfall - spring (October and November 2015) and the other, by lower temperatures and lower precipitation - winter (August and September 2016). The climatic conditions in the experimental period were obtained at the weather station located on Campus II/UNOESTE, in Oct. and Nov. 2015, precipitation, maximum and minimum temperature were 237.8 and $378.4 \mathrm{~mm}, 37.0$ and $36.4{ }^{\circ} \mathrm{C}$, 15.0 and $14.0^{\circ} \mathrm{C}$, respectively. In Aug. and Sep. 2016, precipitation, maximum and minimum temperature were 78.2 and $106.4 \mathrm{~mm}, 34.6$ and $34.0{ }^{\circ} \mathrm{C}, 9.2$ and $8.2{ }^{\circ} \mathrm{C}$, respectively.

\subsection{Analysis of the results}

The results obtained, in each season of the year, were submitted to analysis of variance by the F-test and the comparison of means by the Tukey's test, at $5 \%$ probability, using the Assistat software version 7.7. The average percentage of nutrient removal $\left(\mathrm{NH}_{4}^{+}\right.$and available $\left.\mathrm{P}\right), \mathrm{EC}$ and turbidity by the macrophytes systems was calculated by the Equation 1:

$\mathrm{E}=\mathrm{Ic}-\mathrm{Fc} / \mathrm{Ic} \times 100$

where: $\mathrm{E}=$ Removal efficiency (\%); Ic = Initial concentration $\left(\mathrm{mg} \mathrm{L}^{-1} ; \mu \mathrm{S} \mathrm{cm}^{-1} ; \mathrm{NTU}\right) ; \mathrm{Fc}=$ Final concentration $\left(\mathrm{mg} \mathrm{L}^{-1}\right.$; $\mu \mathrm{S} \mathrm{cm}^{-1}$; NTU).

\section{Results and Discussion}

The averages of the physicochemical characteristics of the swine wastewater in natura that was used, whose measurements were carried out in triplicate, are presented in Table 1.

The EC is considered an important indicator of the concentration of dissolved ions in the water, which are represented by electrically charged particles, as reported by Chamun (2008). However, it is not a parameter existent in the Brazilian legislation for the discharge of wastewater. In the raw wastewater coming from the pig farms of Campus II/UNOESTE under study, the EC was elevated, which, according to CETESB (2009), may be considered an impacted environment, since it presented EC levels above $100 \mu \mathrm{sm}^{-1}$.

Bacteria consume the DO during the oxidation of organic matter (OM), which can result in a significant reduction of DO concentration in the medium and in the death of aquatic organisms. Therefore, the DO is one of the important parameters for characterization of water pollution by organic waste (Von Sperling, 2005). The DO concentrations obtained in the wastewater in natura are

Table 1. Physicochemical characteristics of the swine wastewater in natura.

\begin{tabular}{lcc}
\hline \multicolumn{1}{c}{ Parameters } & $\begin{array}{c}\text { Wastewater } \\
\text { in natura }\end{array}$ & $\begin{array}{c}\text { Discharge } \\
\text { Limit }^{(1)}\end{array}$ \\
\hline $\mathrm{EC}\left(\mu \mathrm{S} \mathrm{cm}^{-1}\right)$ & $4480.06 \pm 0.05$ & $\mathrm{ND}$ \\
$\mathrm{DO}\left(\mathrm{mg} \mathrm{L}^{-1}\right)$ & $0.65 \pm 0.03$ & $>5.0^{(\mathrm{b})}$ \\
Turbidity $(\mathrm{NTU})$ & $642.17 \pm 96.84$ & $100.0^{(\mathrm{b})}$ \\
$\mathrm{NH}_{4}^{+}\left(\mathrm{mg} \mathrm{L}^{-1}\right)$ & $55.44 \pm 0.45$ & $20.0^{(\mathrm{a})}$ \\
$\mathrm{P}\left(\mathrm{mg} \mathrm{L}^{-1}\right)$ & $12.90 \pm 0.99$ & $0.15^{(\mathrm{b})}$ \\
\hline
\end{tabular}

Values expressed as the means \pm standard deviation; $\mathrm{ND}=$ non-determined parameter; ${ }^{1}$ limits determined by CONAMA Resolutions; (a)No. 430/2011 (Brasil, 2011); and

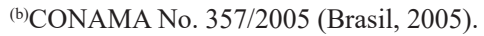
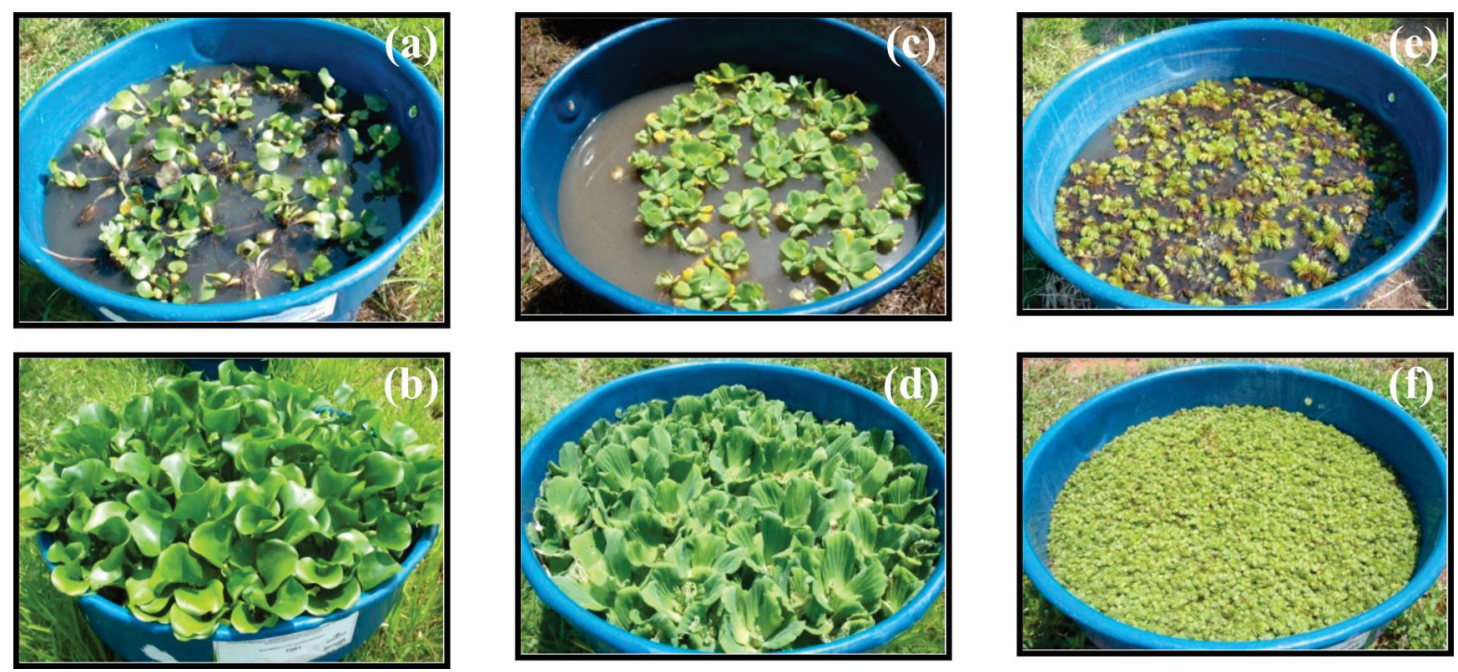

Figure 1. E. crassipes with (a) zero and (b) 30 days of experiment; P. stratiotes with (c) zero and (d) 30 days of experiment; and $S$. auriculata with (e) zero and (f) 30 days of experiment. 
lower than the ones considered appropriate to the discharge of class 2 bodies of water, according to the CONAMA Resolution No. 357/2005 (Brasil, 2005).

The turbidity, on the other hand, represents the measurement of the degree of interference to the passage of light through the liquid. The change in light penetration into the water is due to the presence of material in suspension (Brasil, 2006). Such parameter, determined in the raw wastewater, presented to be, according to Table 1, outside the established standard to the discharge of class 2 bodies of water, by the CONAMA Resolution No. 357/2005 (Brasil, 2005), about six times higher than the allowed limit.

The concentrations of $\mathrm{NH}_{4}^{+}$and $\mathrm{P}$ obtained in the raw wastewater coming from swine also occur in compliance to the quantity allowed by the Brazilian legislation, CONAMA Resolution No. 430/2011 and No. 357/2005 (Brasil, 2011, 2005, respectively).

These physicochemical parameters were also examined in the SW exposed to treatments with E. crassipes, $P$. stratiotes and S. auriculata. Figure 2 presents the EC values of the $\mathrm{SW}$ at the beginning and throughout the period of experiment using the three macrophytes.

The values of EC of the wastewater, obtained at the beginning of the experimental cycle of the warmer period (spring), were relatively high, indicating high concentration of ions and nutrients in the SW (Figure 2a). Martins et al. (2007) found a similar result, in which a progressive elevation of EC was observed by increasing nutrients in the treatments in fish wastewaters with Typha dominguensis, that is, the highest amount of nutrient available at the beginning of the experiments gives a higher EC.

On the other hand, the presence of these ions in the $\mathrm{SW}$ was higher in the winter (Figure $2 \mathrm{~b}$ ), when compared to the spring (Figure 2a), in all collection periods and for all macrophytes that were analyzed. This indicates that, as discussed by Esteves (2011), the EC changes with seasonality and is lower in the rainy season, due to the increased dilution factor of the ions. In addition, in the spring plants have superior stimulus for growth (light, photoperiod, higher temperatures during the day and lower values between day and nighttime temperatures). With this superior stimulus, plants uptake more ions, $\mathrm{K}$, $\mathrm{Na}$, among others, also reducing the EC.
According to Martins et al. (2007), the EC provides information concerning the conditions of the system, such as the availability of nutrients, minerals and organic matter, and is also an indirect measurement of the concentration of pollutants. Brigante and Espíndola (2003) mention that the EC values in natural waters are in the range of 10 to $100 \mu \mathrm{S} \mathrm{cm}^{-1}$ and, in environments polluted by domestic or industrial sewage, can reach $1000 \mu \mathrm{S} \mathrm{cm}^{-1}$. Values that are higher than these were found in the wastewater in natura (Table 1) and in the wastewater from the beginning of all treatments performed in the winter.

Among the proposed treatments, under the conditions that were used, none of them provided a final wastewater with EC quality similar to the one in natural waters. Nonetheless, it should be noted that, at the end of 30 days in the spring, only the treatment with $E$. crassipes provided an SW with EC level below $100 \mu \mathrm{S} \mathrm{cm}^{-1}$ (Figure 2a), similar to the expected concentration in natural waters, as mentioned by Brigante and Espíndola (2003).

The EC values obtained in the winter period (Figure 2b) indicate a small decrease or, in some cases, increase this parameter throughout the collection periods. At the 30th day of contact of the plants with the diluted SW, the treatments with E. crassipes and P. stratiotes did not show a statistically significant difference between them.

When considering the efficiency of plants in the EC reduction of the $\mathrm{SW}$, the treatment with E. crassipes presented $92 \%$ EC reduction in the spring (Figure 2a) and $6.3 \%$ in the winter (Figure $2 \mathrm{~b}$ ), whereas P. stratiotes reduced $70.1 \%$ of EC in the spring (Figure $2 \mathrm{a}$ ) and $2.0 \%$ in the winter (Figure 2b). S. auriculata, on the other hand, reduced $53.6 \%$ of EC in the spring (Figure 2a), and in the winter there was no reduction of this parameter. Therefore, E. crassipes and $P$. stratiotes had higher ion uptake capacity in periods with higher temperatures.

Figure 3 shows the DO concentrations in the SW exposed to the treatment with macrophytes, at the beginning and during the experimental period.

The DO concentrations observed in the SW treated by the aquatic macrophytes were low and the values obtained in the spring (Figure 3a) show that there was no significant increase throughout the periods of experimentation and collection, except for $S$. auriculata that, in the period of
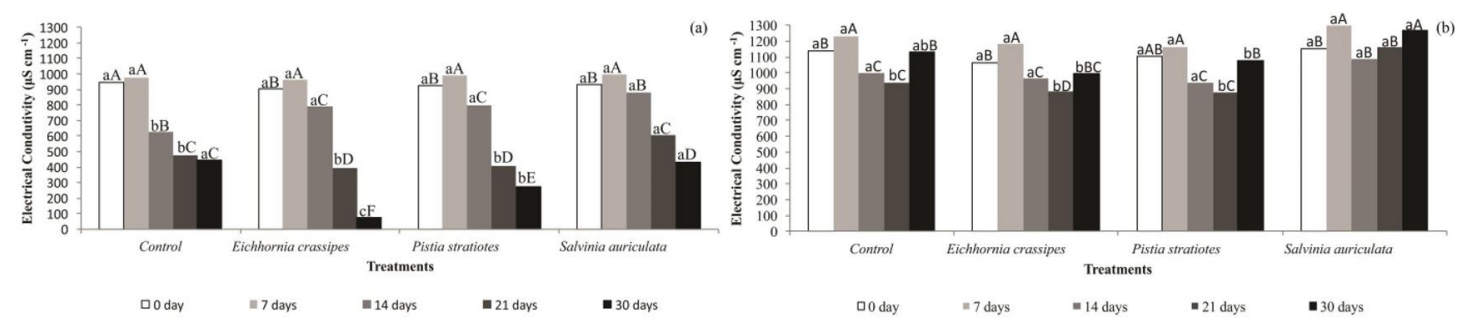

Figure 2. Values of electrical conductivity, in $\mu \mathrm{S} \mathrm{cm}^{-1}$, obtained in the $\mathrm{SW}$ after treatment with the aquatic species, in five collection periods, (a) in the spring and (b) in the winter. Notes: $\mathrm{msd}$ and $\mathrm{CV}(\%)$ for treatments $=121.60 ; 3.83$ (a) and $181.81 ; 3.19$ (b) classification with lowercase letters. msd and CV(\%) for periods $=53.18 ; 17.32$ (a) and 70.76; 16.32 (b) classification with uppercase letters. Values followed by equal letters do not show significant difference by the Tukey's test with $5 \%$ probability. $\mathrm{msd}=$ minimum significant difference; $\mathrm{CV}=$ Coefficient of Variation. 
30 days, which provided an increase in the DO concentration of the SW.

According to Henry-Silva and Camargo (2008), the reduced concentration of DO observed in the SW exposed to the treatment with macrophytes in the spring (Figure 3a) may be related to the shading of the water column, which hinders the phytoplankton development and the decomposition of the OM adhered to the root system of $E$. crassipes and $P$. stratiotes, both of which present a dense root system. It can be evidenced by the behavior of the control treatment, which showed an increase in the DO concentrations throughout the experimental period. Still in accordance with Henry-Silva and Camargo (2008), the incidence of solar rays on the surface of the wastewater without plants increases the temperature values and favors the development of filamentous algae, which contribute to increase the $\mathrm{DO}$ concentrations.

Still using Henry-Silva and Camargo (2008), the incidence of solar rays on the surface of the wastewater without plants increases the temperature numbers and favors the development of filamentous algae, which contribute to the increase of the DO concentrations.

In order to evaluate the treatment of fish wastewater with aquatic macrophytes (E. crassipes, $P$. stratiotes and S. molesta), Henry-Silva (2001) observed the development of phytoplankton in tanks without macrophytes, what, probably, increased the DO levels in the water during the day. Furthermore, Esteves (1998) states that the increase of organic matter in the water associated with high temperatures is determinant in the decrease of the DO concentration. Based on this information, it is important to emphasize that the data presented in Figure 3a were collected in an environment with higher temperatures (Oct. and Nov.).

The results show that, in this warmer period, the DO levels in systems with macrophytes were always below $6.0 \mathrm{mg} \mathrm{L}^{-1}$ (Figure 3a), what can be explained by the non-occurance of movement of the wastewater in the treatment boxes, which can be characterized as a lentic environment. In lotic systems, where there is constant renewal and movement of the water in the channels, with flow above $4000 \mathrm{~L} \mathrm{~h}^{-1}$, the gas exchanges between the aquatic environment and the atmospheric oxygen are boosted, allowing the achievement of DO levels above
$6.0 \mathrm{mg} \mathrm{L}^{-1}$ (Silva et al., 2014). Thereby, the absence of agitation of the wastewater may have compromised the DO levels in the treated wastewater.

For the DO concentration, there was no statistical difference between the treatments proposed in the winter period, except in the period of 21 days, when this concentration was higher in the treatments with E. crassipes and P. stratiotes (Figure 3b). However, throughout the collection periods, there was an increase in the DO concentration in all treatments, with exception to the treatment with S. auriculata. Probably, in this cycle, which is characterized by mild temperatures, the biomass production was not as high as in the first one, not providing total shading of the water column and not preventing the phytoplankton development and the diffusion of $\mathrm{O}_{2}$ into the wastewater. Moreover, the milder temperatures in the months of Aug. and Sep. may have contributed to increase the DO concentrations, since, according to Henry-Silva and Camargo (2008), higher temperatures contribute to the reduction of the DO concentrations, due to the decrease of the solubilization of such gas.

Figure 4 presents the turbidity data of the SW exposed to the process of phytoremediation by macrophytes.

From the data obtained in the spring (Figure 4a), a reduction in the turbidity values of the wastewater was observed, during the periods of experimentation; however, these values increased in the SW exposed to the treatments with $E$. crassipes and $P$. stratiotes, at the end of the 30 days of evaluation. Probably, this increase is associated with the long-term permanence and development of the plants in the system, because, according to Cunha-Santino and Bianchini Júnior (2000), after the senescence of the aquatic plants, large amounts of water-soluble cellular components are released quickly. In the period of 21 days, the reduction of turbidity was more significant for these two species.

The reduction of turbidity may be related to the detention time of the wastewater in the system. Borges et al. (2008), when assessing a system of flooded areas with the macrophyte $E$. crassipes, obtained a turbidity removal rate of $96.8 \%$ for a detention period of 20 days. In the present study, the removal rate obtained in the period of spring (Figure 4a) to the water hyacinth in the period of 21 days was $82.2 \%$, and, in the period of 30 days, the removal rate
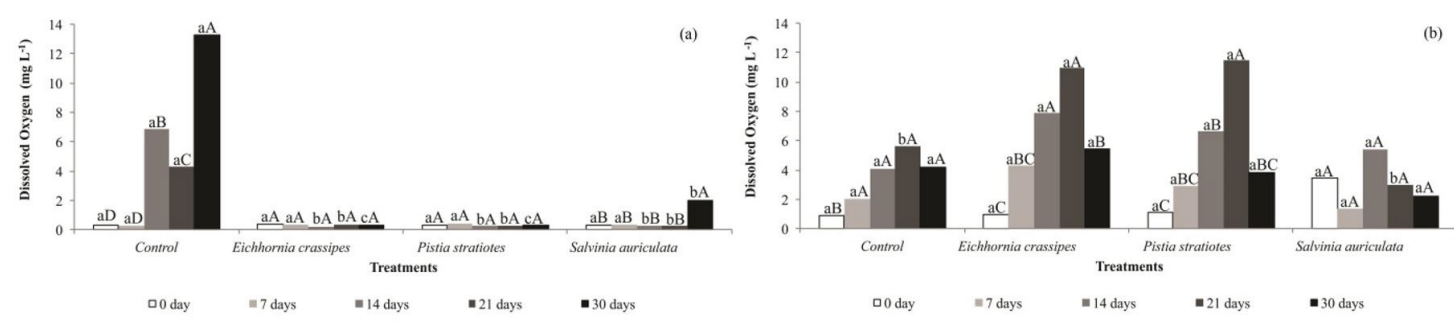

Figure 3. Concentration of dissolved oxygen, in $\mathrm{mg} \mathrm{L}^{-1}$, obtained in the $\mathrm{SW}$ after treatment with the aquatic species, in five collection periods, (a) in the spring and (b) in the winter. Notes: msd and CV(\%) for treatments $=0.97 ; 31.42$ (a) and 4.19; 56.62 (b) classification with lowercase letters. msd and $\mathrm{CV}(\%)$ for periods $=0.99 ; 37.52$ (a) and 4.34; 49.32 (b) classification with uppercase letters. Values followed by equal letters do not show significant difference by the Tukey's test with $5 \%$ probability. $\mathrm{msd}=$ minimum significant difference; $\mathrm{CV}=$ Coefficient of Variation. 
reduced to $56.3 \%$ in relation to the turbidity present in the wastewater in the initial period of the experiment. It was also observed that, in the first cycle (spring), at the end of 30 days, the reduction of turbidity was more expressive in the treatment with $S$. auriculata, since this species grows more slowly and, consequently, the decomposition of the wastewater pollutants is also slower and the values of turbidity are lower. It is important to note that the processes for reducing turbidity consist in the removal of suspended solids responsible for it.

In the winter (Figure 4b), the most significant reduction of turbidity occurred with the treatment with $E$. crassipes, in the period of 30 days. Probably, the efficiency of the system with $E$. crassipes when reducing turbidity was higher, as well as in Henry-Silva and Camargo (2008) study, due to the large root development of this species and to the low depth of the tanks, which created favourable conditions for the adsorption and precipitation of the suspended particulate matter. Interestingly, in this evaluation cycle, only the wastewater treatment with $E$. crassipes reached values lower than $100 \mathrm{NTU}$ at the end of 30 days. Since the CONAMA Resolution No. 357/2005 (Brasil, 2005) limits the turbidity values to $100 \mathrm{NTU}$ in classes 2 and 3 bodies of water, the aforementioned treatment with this species provided an wastewater in accordance with the legal standards allowed in the country.
The concentration of $\mathrm{NH}_{4}^{+}$was also determined in the wastewater exposed to E. crassipes, $P$. stratiotes and S. auriculata and the results are presented in Figure 5.

The concentrations of $\mathrm{NH}_{4}^{+}$obtained in the $\mathrm{SW}$ in the spring (Figure 5a) show that, although no statistical difference was observed in the management with the different plants, there was a tendency of decreasing the content of $\mathrm{NH}_{4}^{+}$for all species, between the period of 0 and 30 days. The species E. crassipes presented an $80.2 \%$ removal efficiency of $\mathrm{NH}_{4}^{+}$, followed by $\mathrm{S}$. auriculata and P. stratiotes with 78.7 and $70.0 \%$, respectively, whereas in the control treatment there was $67.9 \%$ reduction of the levels of $\mathrm{NH}_{4}^{+}$. Sezerino and Philippi (2000) point out that, in these wastewater treatment systems using plants, approximately $74.0 \%$ of the $\mathrm{NH}_{4}^{+}$removal can be associated with the uptake by plants. In the winter cycle (Figure 5b), similar to spring, all treatments provided a reduction in the concentration of $\mathrm{NH}_{4}^{+}$and the specie that provided the greater efficiency was $E$. crassipes, with a $76.8 \%$ removal.

Figure 6 presents the levels of available P obtained in the spring and in the winter (b) at the beginning of the treatment and the end of 30 days. In the treatment with E. crassipes, during the spring, the reduction of $\mathrm{P}$ in the wastewater (Figure 6a) was noticed, what evidences the potential of this species in the assimilation of this nutrient. According to Diniz et al. (2005), the reduction of phosphorus
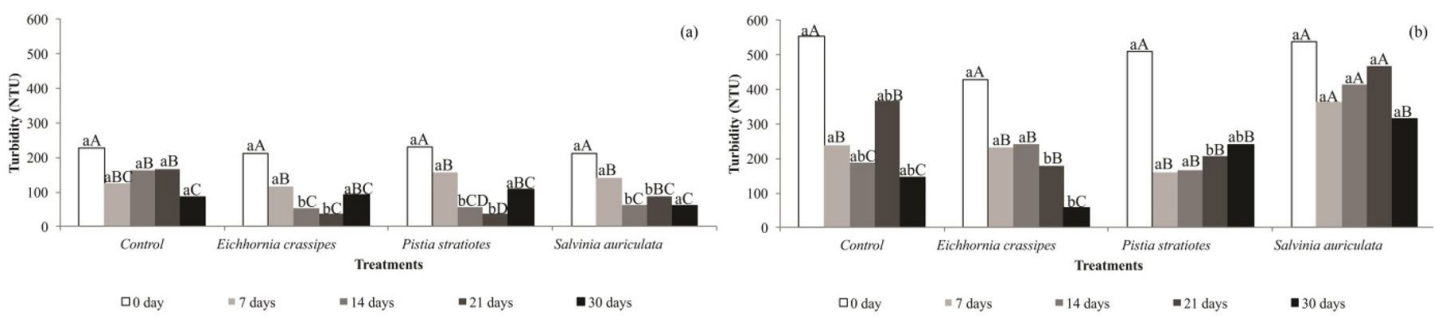

Figure 4. Turbidity values, in NTU, obtained in the SW after treatment with the aquatic species, in five collection periods, (a) in the spring and (b) in the winter. Notes: $m s d$ and $C V(\%)$ for treatments $=53.23 ; 22.54$ (a) and 251.87;29.71 (b) classification with lowercase letters. msd and $\mathrm{CV}(\%)$ for periods $=54.80 ; 26.52$ (a) and 179.02; 74.69 (b) classification with uppercase letters. Values followed by equal letters do not show significant difference by the Tukey's test with $5 \%$ probability. $\mathrm{msd}=$ minimum significant difference; $\mathrm{CV}=$ Coefficient of Variation.
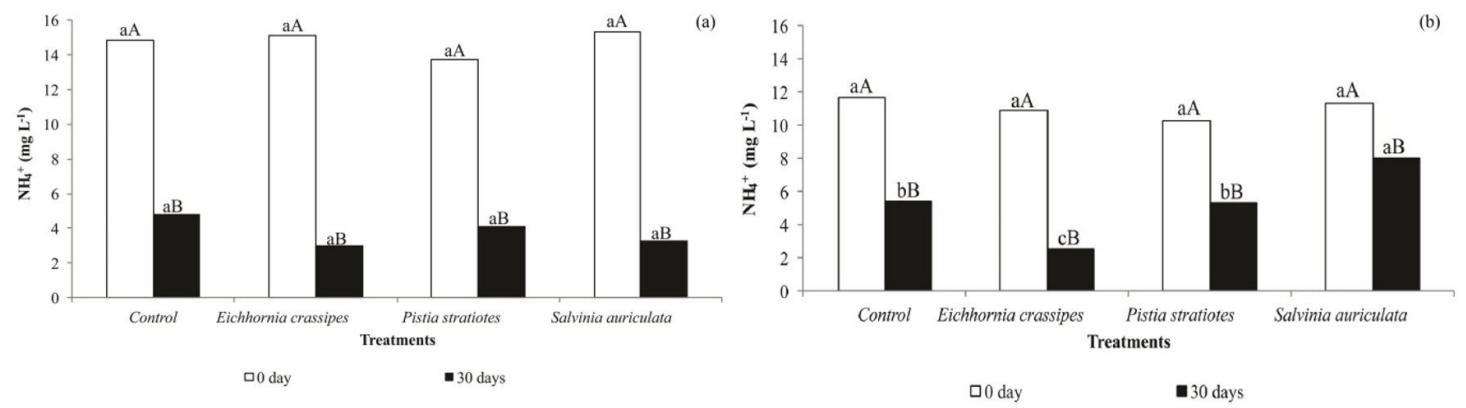

Figure 5. $\mathrm{NH}_{4}^{+}$values, in $\mathrm{mg} \mathrm{L}^{-1}$, obtained in the $\mathrm{SW}$ after treatment with the aquatic species, in two collection periods, (a) in the spring and (b) in the winter. Notes: msd and $\mathrm{CV}(\%)$ for treatments $=1.80 ; 10.55$ (a) and 2.01; 11.88 (b) classification with lowercase letters. msd and CV(\%) for periods $=1.51 ; 9.12$ (a) and 1.50; 12.97 (b) classification with uppercase letters. Values followed by equal letters do not show significant difference by the Tukey's test with $5 \%$ probability. msd = minimum significant difference; $\mathrm{CV}=$ Coefficient of Variation. 

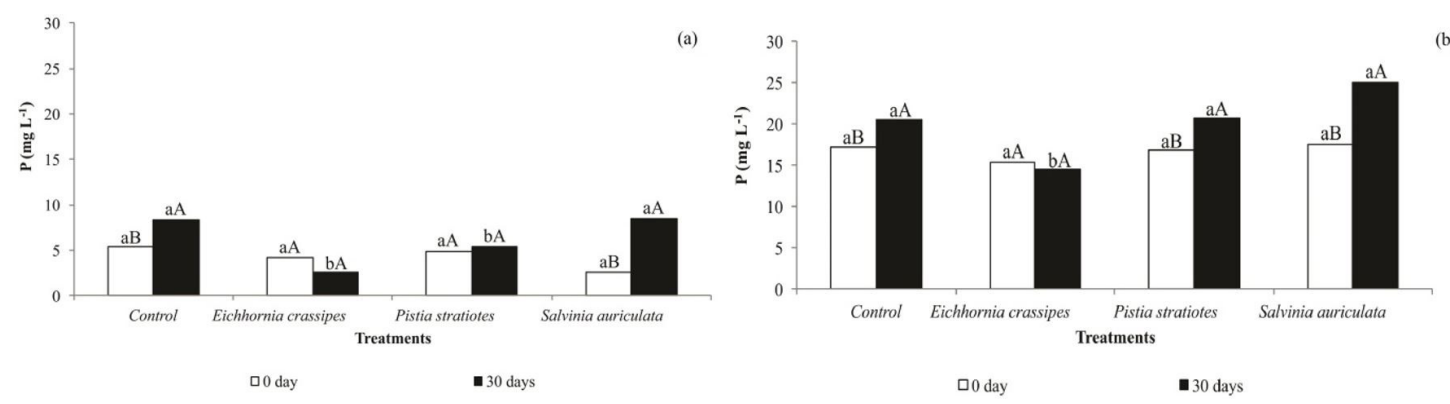

Figure 6. $\mathrm{P}$ values, in $\mathrm{mg} \mathrm{L}^{-1}$, obtained in the $\mathrm{SW}$ after treatment with the aquatic species, in two collection periods, (a) in the spring and (b) in the winter. Notes: msd and CV(\%) for treatments $=28.58 ; 28.58$ (a) and 5.97; 11.27 (b) classification with lowercase letters. msd and $\mathrm{CV}(\%)$ for periods $=2.29 ; 27.24$ (a) and 3.20; 19.42 (b) classification with uppercase letters. Values followed by equal letters do not show significant difference by the Tukey's test with $5 \%$ probability. msd $=$ minimum significant difference; CV $=$ Coefficient of Variation.

concentration mainly occurs through its assimilation by the aquatic plants, converting it into cellular material and part is precipitated under different chemical forms. However, in the other treatments (control treatment, $P$. stratiotes and $S$. auriculata), there was an increase in the content of $\mathrm{P}$ of the SW compared to the beginning of the experimental cycle, what may be related to decomposition of organic matter of the wastewater, releasing the phospurus that was initially linked to organic compounds.

The removal rate of $\mathrm{P}$ of the wastewater under the action of E. crassipes in the spring was $39 \%$, as compared to day 0 (Figure $6 \mathrm{a}$ ). This reduction is rather significant, since the nutrients, $\mathrm{N}$ and $\mathrm{P}$, are difficult to be removed through biological systems and typically require specific and tertiary processes to their removal. The obtained removal confirms the results found by Weirich (2009) that verified a $37.6 \%$ P removal with E. crassipes, in post-treatment of $\mathrm{SW}$, during the spring.

In the winter, there was also an increase of the levels of $\mathrm{P}$ in the wastewater of the control treatment and the ones with $P$. stratiotes and $S$. auriculata (Figure 6b). The treatment with $E$. crassipes differed statically from the others in the period of 30 days; however, it showed a P reduction rate of only $5.8 \%$, compared to the beginning of the experiment ( 0 day). Mees et al. (2009), when evaluating the performance of the aquatic macrophyte E. crassipes in a treatment system of slaughterhouses and meat processing facilities, observed that the removal of nutrients and organic matter were higher at the beginning of the experiment, with a noticeable reduction starting in June. Probably, in the present study, the reduction of $\mathrm{P}$ content was also lower in this cycle, carried out in August, due to the lower temperatures.

Seasonal variations have an effect on the development of aquatic plants, what was found by Olivie-Lauquet et al. (2001), in flooded systems. The highest reduction rate of $\mathrm{P}$ obtained in this study, using E. crassipes during the spring, may be linked to the higher temperatures and photoperiod, which facilitated the development of the plants (Diniz et al., 2005).
The levels of $\mathrm{NH}_{4}^{+}$and total $\mathrm{P}$ in the plant tissues of the aquatic plants, obtained after 30 days of exposure to SW in the spring and winter, are presented in Figure 7.

Total plants dry matter nutrient composition, before they were exposed to the SW, was: $22.8,22.0$ and $13.0 \mathrm{~g} \mathrm{~kg}^{-1}$ of $\mathrm{NH}_{4}^{+}$, and 2.2, 4.4, and 0.9 of total $\mathrm{P}$ for E. crassipes, $P$. stratiotes and $S$. auriculata, respectively. The levels of $\mathrm{NH}_{4}^{+}$(Figure 7a) in the plants, compared to the one from the initial characterization showed an increase in the spring and winter of, respectively, 1.6 and 1.5 times for E. crassipes and 2.2 and 3.5 times for $S$. auriculata, whereas for P. stratiotes, both in the spring and winter, this increase was 2.2 times. The increases in the levels of $\mathrm{NH}_{4}^{+}$in the plants after 30 days of contact with the SW prove the high potential of these species in the uptake of such element. Both in the period of spring and winter, $P$. stratiotes presented a prominence in the content of $\mathrm{NH}_{4}^{+}$in its tissues (Figure 7a) and, in addition, it also showed higher reduction in the levels of this element in the SW treated by this plant (Figure $5 \mathrm{a}$ and $5 \mathrm{~b}$ ). The results demonstrated that $\mathrm{NH}_{4}^{+}$uptake in the plant provided a substantial impact on the removal of $\mathrm{NH}_{4}^{+}$from swine wastewater.

There was no significant differentiation in levels of total $P$ between the three species (Figure 7b), revealing that, as well as the levels of $\mathrm{NH}_{4}^{+}$, they are able to develop and extract nutrients, even in milder weather conditions. Comparing the levels of total $P$ from the initial characterization of the plants to those obtained after the completion of 30 days of exposure to the SW, it was found that there was an increase in the amount of phosphorus in the plants. Also, increases were observed in the spring and winter as it follows, respectively: 3.7 and 4.4 times for E. crassipes, 2.9 and 1.9 for $P$. stratiotes and 8.2 and 10.9 for $S$. auriculata.

The uptake of nutrients by aquatic plants is essential for their growth and reproduction and their high productivity allows significant amounts of nutrients to be extracted and stored in the plant biomass (Shah et al., 2015). Plant growth assimilates nutrients to form organic compounds such that when the plants are harvested, the $\mathrm{N}$ and $\mathrm{P}$ are 

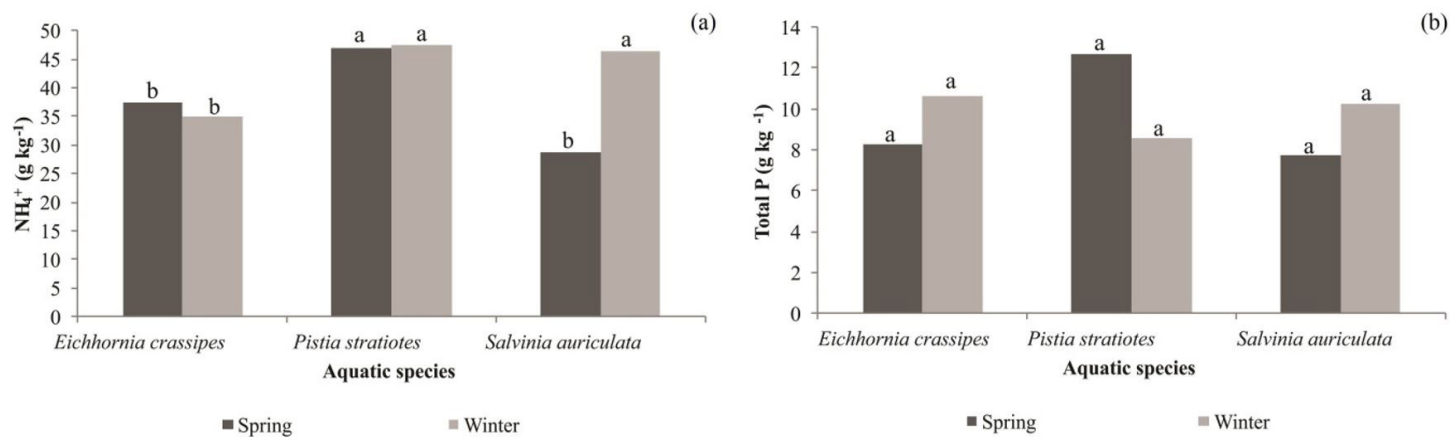

Figure 7. Levels of (a) $\mathrm{NH}_{4}^{+}$and (b) total $\mathrm{P}$, in $\mathrm{g} \mathrm{kg}^{-1}$, of the aquatic species, in the spring and in the winter. Notes: msd and $\mathrm{CV}(\%)$ for spring $=9.23 ; 11.28$ (a) and 5.79; 25.00 (b). msd and CV(\%) for winter = 4.94; 5.31 (a) and 2.46; 11.58 (b). Values followed by equal letters do not show significant difference by the Tukey's test with $5 \%$ probability. msd = minimum significant difference; $\mathrm{CV}=$ Coefficient of Variation.

removed from the polluted water bodies (Vymazal, 2007). In this context, the production of dry matter biomass (DMS) was determined for the three species, which are presented in Figure 8.

In the spring, the highest production of dry biomass was obtained for E. crassipes, with $0.62 \mathrm{~kg} \cdot \mathrm{m}^{-2}$, whereas for $P$. stratiotes and $S$. auriculata, the production of DMB was $0.21 \mathrm{~kg} \cdot \mathrm{m}^{-2}$ and $0.10 \mathrm{~kg} \cdot \mathrm{m}^{-2}$, respectively (Figure 8). Mees et al. (2009), using E. crassipes in wastewater treatment system of slaughterhouse and meat processing facilities, obtained, in the first eight weeks, the average production of $16.21 \mathrm{~kg} \mathrm{~m}^{-2}$. The results obtained in this study were smaller than the ones obtained by Mees et al. (2009); probably due to the fact that the area occupied by the plants hereby used was smaller, corresponding to $1.0 \mathrm{~m}^{2}$ for each of the species, since the aforementioned author used a $35.0 \mathrm{~m}^{2}$ area.

Moreover, the climatic conditions in the two evaluated periods had an influence in the amount of biomass produced. In the winter, the production of DMB was lower, for the three species (E. crassipes, P. stratiotes and s. auriculata), when compared to the production obtained in the spring. According to Silva et al. (2014), the increase in the temperature can positively influence the increase in the biomass. Supporting this hypothesis, Gentelini et al. (2008), using E. crassipes in the wastewater treatment of organic fish farming at a temperature of $18.7^{\circ} \mathrm{C}$, obtained an average production of $8.03 \mathrm{~kg} \mathrm{~m}^{-2}$, which was lower than the one found by Silva et al. (2014), which, using E. crassipes in the treatment of fish farming wastewater, at a temperature between 27.9 and $29.2{ }^{\circ} \mathrm{C}$, reached a production of $21.64 \mathrm{~kg} \mathrm{~m}^{-2}$.

In the winter, there was an increase of DMB equivalent to $159.3 \%$ for E. crassipes (Figure 8), due to the uptake of nutrients available in the SW by the plants, as quoted by Gentelini et al. (2008). However, the production of biomass was higher in spring (2.2 times for E. crassipes, and for P. stratiotes, and 1.9 times for S. auriculata), since the temperatures were higher, confirming the statement of Silva et al. (2014).

According to Sipaúba-Tavares et al. (2002), in addition to the temperature, the light intensity and the availability

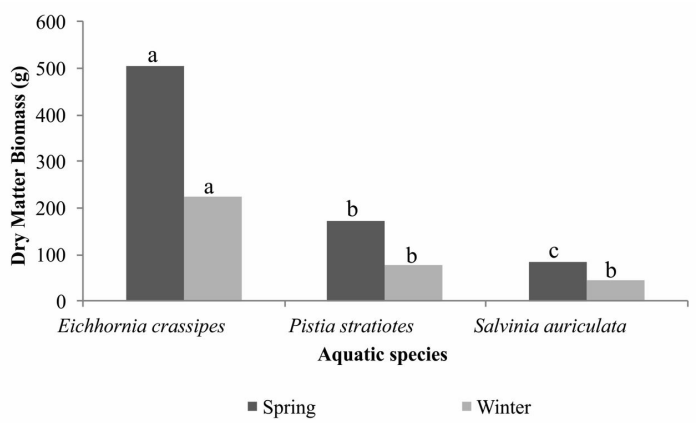

Figure 8. Dry biomass produced, in g, of the aquatic species, in the spring and in the winter. Notes: msd and $\mathrm{CV}(\%)$ for spring $=65.81 ; 11.93$. msd and $\mathrm{CV}(\%)$ for winter $=46.74 ; 18.57$. Values followed by equal letters do not show significant difference by the Tukey's test with $5 \%$ probability. $\mathrm{msd}=$ minimum significant difference; $\mathrm{CV}=$ Coefficient of Variation .

of nutrients, such as phosphorus, may have influenced the productivity of these macrophytes. As a result, it is possible to infer that the increase in the biomass of the three macrophytes may have been influenced by the difference of photoperiod and the intensity of the radiation, which are higher in the spring.

Thus, it is observed that the production of biomass will depend, in addition to the climatic conditions, on the type and concentration of the aqueous matrix to which the species will be exposed. Furthermore, it will depend on the sensitivity of the species to the wastewater, since they present distinct and variable uptake of nutrients.

It is important to highlight that Weirich (2009), when evaluating the biomass production of $E$. crassipes and $P$. stratiotes, during winter and summer, in the tertiary treatment of SW, observed that the results of final biomass gain per day for E. crassipes were $134.0 \mathrm{~g} \mathrm{~m}^{-2}$ day $^{-1}$ during the summer and $106.0 \mathrm{~g} \mathrm{~m}^{-2}$ day $^{-1}$ in the winter, what revealed that $E$. crassipes presented a large capacity of biomass production, even under low temperature conditions. 


\section{Conclusions}

It is possible to conclude that, in the spring, the species E. crassipes, $P$. stratiotes and S. auriculata presented higher production of dry biomass, with a more expressive reduction in the values of $\mathrm{EC}, \mathrm{NH}_{4}^{+}$and $\mathrm{P}$, when compared to the plants that were handled in the swine wastewater in the winter. E. crassipes was more efficient during the spring in the removal of $39 \%$ of $\mathrm{P}$ and $80.2 \%$ of total $\mathrm{NH}_{4}^{+}$, as well as in the reduction of $92 \%$ of EC of the swine wastewater and in the production of dry biomass.

\section{References}

AMORIM, F., FIA, R., FRANÇA, F.A., TERRA, L.M. and FIA, F.R.L., 2015. Unidades combinadas RAFA-SAC para tratamento de água residuária de suinocultura. Parte I: carga orgânica removida. Engenharia Agrícola, vol. 35, no. 6, pp. 1149-1159. http://dx.doi. org/10.1590/1809-4430-Eng.Agric.v35n6p1149-1159/2015.

ASSOCIAÇÃO BRASILEIRA DOS CRIADORES DE SUÍNOS ABCS, 2016 [viewed 20 July 2018]. Mapeamento da suinocultura brasileira [online]. 1. ed. Brasília. Available from: http://www. abcs.org.br/attachments/-01 Mapeamento_COMPLETO bloq.pdf

BIAŁOWIEC, A., JANCZUKOWICZ, W. and RANDERSON, P.F., 2011. Nitrogen removal from wastewater in vertical flow constructed wetlands containing LWA/gravel layers and reed vegetation. Ecological Engineering, vol. 37, no. 6, pp. 897-902. http://dx.doi.org/10.1016/j.ecoleng.2011.01.013.

BORGES, A.K.P., TAUK-TORNISIELO, S.M., DOMINGOS, R.N. and ANGELIS, D.F., 2008. Performance of the constructed wetland system for the treatment of water from the Corumbatai river. Brazilian Archives of Biology and Technology, vol. 51, no. 6, pp. 1-9. http://dx.doi.org/10.1590/S1516-89132008000600024.

BRASIL. Conselho Nacional de Meio Ambiente - CONAMA, 2005 [viewed 2 August 2018]. Resolução $n^{\circ} 357$, de 17 de março de 2005. Dispõe sobre a classificação dos corpos de água e diretrizes ambientais para o seu enquadramento, bem como estabelece as condições e padrões de lançamento de efluentes, e dá outras providências [online]. Diário Oficial da República Federativa do Brasil, Brasilia, 18 março. Available from: http:// www.mma.gov.br/port/conama/legiabre.cfm?codlegi=459

BRASIL. Ministério da Saúde, 2006 [viewed 2 August 2018]. Vigilância e controle da qualidade da água para consumo humano [online]. Brasília. Available from: http://bvsms.saude.gov.br/bvs/ publicacoes/vigilancia_controle_qualidade_agua.pdf

BRASIL. Conselho Nacional de Meio Ambiente - CONAMA, 2011 [viewed 2 August 2018]. Resolução $n^{\circ} 430$, de 13 de maio de 2011. Dispõe sobre as condições e padrões de lançamento de efluentes, complementa e altera a Resolução no 357, de 17 de março de 2005, do Conselho Nacional do Meio AmbienteCONAMA [online]. Diário Oficial da República Federativa do Brasil, Brasilia, 13 maio. Available from: http://www.mma.gov. br/port/conama/legiabre.cfm?codlegi $=646$

BRIGANTE, J. and ESPÍNDOLA, E.L.G., 2003. Limnologia fluvial: um estudo no Rio Mogi-Guaçu. São Carlos: Rima.

CAMARGO, A.F.M. and ESTEVES, F.A., 1995. Biomass and productivity of aquatic macrophytes in Brazilian lacustrine ecosystems. In: J.G. TUNDISI, C.E.M. BICUDO and T. MATSUMURA-TUNDISI, eds. Limnology in Brazil. Rio de Janeiro: ABC/SBL, pp. 137-149.
CHAMUN, C.C., 2008. Avaliação da poluição difusa de esgoto doméstico veiculado à bacia hidrográfica urbana. Santa Maria: Universidade Federal de Santa Maria, 157 p. Dissertação de Mestrado em Engenharia Civil.

COMPANHIA AMBIENTAL DO ESTADO DE SÃO PAULO CETESB, 2009 [viewed 2 August 2018]. Significado ambiental e sanitário das variáveis de qualidade das águas e dos sedimentos e metodologias analiticas e de amostragem [online]. São Paulo. Available from: https://cetesb.sp.gov.br/aguas-interiores/wp-content/ uploads/sites/12/2017/11/Apêndice-E-Significado-Ambiental-eSanitário-das-Variáveis-de-Qualidade-2016.pdf

CUNHA-SANTINO, M.B. and BIANCHINI JÚNIOR, I., 2000. Decomposição aeróbia e anaeróbia de Salvinia auriculata Aubl. da lagoa do Infernão. In: J.E. SANTOS and J.S.R. PIRES, eds. Estudos integrados em ecossistemas: Estação Ecológica de Jataí. São Carlos: RiMa, pp. 631-643.

DINIZ, C.R., CEBALLOS, B.O., BARBOSA, J.E.L. and KONIG, A., 2005. Uso de macrófitas aquáticas como solução ecológica para melhoria da qualidade de água. Revista Brasileira de Engenharia Agrícola e Ambiental, vol. 9, suppl., pp. 226-230.

ESTEVES, F.A., 1998. Fundamentos de limnologia. 2. ed. Rio de Janeiro: Interciência.

ESTEVES, F.A., 2011. Fundamentos de limnologia. 3. ed. Rio de Janeiro: Interciência.

GENTELINI, A.L., GOMES, S.D., FEIDEN, A., ZENATTI, D., SAMPAIO, S.C. and COLDEBELLA, A., 2008. Produção de biomassa das macrófitas aquáticas Eichhornia crassipes (aguapé) e Egeria densa (egeria) em sistema de tratamento de efluente de piscicultura orgânica. Revista Semina: Ciências Agrárias, vol. 29, no. 2, pp. 441-448. http://dx.doi.org/10.5433/16790359.2008v29n2p441.

HENRY-SILVA, G.G. and CAMARGO, A.F.M., 2008. Tratamento de efluentes de carcinicultura por macrófitas aquáticas flutuantes. Revista Brasileira de Zootecnia, vol. 37, no. 2, pp. 181-188. http:// dx.doi.org/10.1590/S1516-35982008000200002.

HENRY-SILVA, G.G., 2001. Utilização de macrófitas aquáticas flutuantes (Eichhornia crassipes, Pistia stratiotes e Salvinia molesta) no tratamento de efluentes de piscicultura e possibilidades de aproveitamento da biomassa vegetal. Jaboticabal: Universidade Estadual Paulista, 56 p. Dissertação de Mestrado em Aquicultura.

MALAVOLTA, E., VITTI, G.C. and OLIVEIRA, S.A., 1997. Avaliação do estado nutricional das plantas: princípios $e$ aplicações. 2. ed. Piracicaba: Potafós, 319 p.

MARTINS, A.P.L., REISSMANN, C.B., FAVARETTO, N., BOEGER, M.R.T. and OLIVEIRA, E.B., 2007. Capacidade da Typha dominguensis na fitorremediação de efluentes de tanques de piscicultura na Bacia do Iraí - Paraná. Revista Brasileira de Engenharia Agrícola e Ambiental, vol. 11, no. 3, pp. 324-330. http://dx.doi.org/10.1590/S1415-43662007000300013.

MEES, J.B.R., GOMES, S.D., BOAS, M.A.V., FAZOLO, A. and SAMPAIO, S.C., 2009. Removal of organic matter and nutrients from slaughterhouse wastewater by using Eichhornia crassipes and evaluation of the generated biomass composting. Engenharia Agrícola, vol. 29, no. 3, pp. 466-473. http://dx.doi. org/10.1590/S0100-69162009000300013.

OLIVIE-LAUQUET, G., GRUAU, G., DIA, A., RIOU, C., JAFFREZIC, A. and HENIN, O., 2001. Release of trace elements in wetlands: role of seasonal variability. Water Research, vol. 35, no. 
4, pp. 943-952. http://dx.doi.org/10.1016/S0043-1354(00)003286. PMid: 11235890.

RODRIGUES, L.S., SILVA, I.J., ZOCRATO, C.O.M., PAPA, D.N., SPERLING, M.V. and OLIVEIRA, P.R., 2010. Avaliação de desempenho de reator UASB no tratamento de águas residuárias de suinocultura. Revista Brasileira de Engenharia Agrícola e Ambiental, vol. 14, no. 1, pp. 94-100. http://dx.doi.org/10.1590/ S1415-43662010000100013.

SEZERINO, P.H. and PHILIPPI, L.S., 2000. Utilização de um sistema experimental por meio de "wetland" construído no tratamento de esgotos domésticos pós tanque séptico. In: Anais do Simpósio Luso-Brasileiro de Engenharia Sanitária e Ambiental, 2000, Porto Seguro. Porto Seguro: ABES, pp. 688-697.

SHAH, M., HASHMI, H.N., GHUMMAN, A.R. and ZEESHAN, M., 2015. Performance assessment of aquatic macrophytes for treatment of municipal wastewater. Journal of the South African Institution of Civil Engineering, vol. 57, no. 3, pp. 18-25. http:// dx.doi.org/10.17159/2309-8775/2015/V57N3A3.

SHELEF, O., GROSS, A. and RACHMILEVITCH, S., 2013. Role of plants in a constructed wetland: current and new perspectives. Water, vol. 5, no. 2, pp. 405-419. http://dx.doi. org/10.3390/w5020405.

SILVA, A.D.R., SANTOS, R.B., BRUNO, A.M.S.S., GENTELINI, A.L., SILVA, A.H.G. and SOARES, E.C., 2014. Eficiência do aguapé sobre variáveis limnológicas em canais de abastecimento utilizados no cultivo de tambaqui. Acta Amazonica, vol. 44, no. 2, pp. 255-262. http://dx.doi.org/10.1590/S0044-59672014000200011.

SIPAÚBA-TAVARES, L.H., FAVERO, E.G.P. and BRAGA, F.M.S., 2002. Utilization of macrophyte biofilter in effluent from aquaculture: I. floating plant. Brazilian Journal of Biology $=$ Revista Brasileira de Biologia, vol. 62, no. 4, pp. 713-723. http:// dx.doi.org/10.1590/S1519-69842002000400019. PMid:12659021.

SONG, M., SHIN, S.G. and HWANG, S., 2010. Methanogenic population dynamics assessed by real-time quantitative PCR in sludge granule in upflow anaerobic sludge blanket treating swine wastewater. Bioresource Technology, vol. 101, no. 1, suppl. 1, pp. 523-528. http://dx.doi.org/10.1016/j.biortech.2009.03.054. PMid:19369072.

VON SPERLING, M., 2005. Introdução à qualidade das águas e ao tratamento de esgotos. 3. ed. Belo Horizonte.

VYMAZAL, J., 2007. Removal of nutrients in various types of constructed wetlands. The Science of the Total Environment, vol. 380, no. 1-3, pp. 48-65. http://dx.doi.org/10.1016/j. scitotenv.2006.09.014. PMid:17078997.

WEIRICH, C.E., 2009. Influência da temperatura sobre plantas aquáticas em pós-tratamento de efluente da suinocultura. Marechal Cândido Rondon: Universidade Estadual do Oeste do Paraná, 60 p. Dissertação de Mestrado em Agronomia. 